\title{
ANTI-HYPERGLYCAEMIC AND ANTI-OXIDANT ACTIVI- TIES OF FIVE NIGERIAN ANTIDIABETIC PLANTS
}

\author{
M.D. Ayoola ${ }^{1}$, *A. C. Adebajo ${ }^{1,3}$, E. M. Obuotor ${ }^{2}$, T. O. Oladapo ${ }^{1}$ and T. C. Fleischer ${ }^{3}$ \\ ${ }^{I}$ Department of Pharmacognosy, Faculty of Pharmacy, Obafemi Awolowo University, Ile Ife, \\ Osun State. Nigeria \\ ${ }^{2}$ Department of Biochemistry and Biotechnology, Faculty of Science, Obafemi Awolowo University \\ Ile Ife, Osun State. Nigeria \\ ${ }^{3}$ Department of Pharmacognosy and Herbal Medicine, School of Pharmacy, \\ University of Health and Allied Sciences, Ho, Ghana \\ *Corresponding author:caadebajo@gmail.com; cadebajo@uhas.edu.gh.
}

\begin{abstract}
Leaves of Olax subscorpioidea, Hoslundia opposita, Cleistopholis patens, Plumbago zeylanica and Dioscoreophyllum cumminsii that are used as anti-diabetics were evaluated for hyperglycaemic-lowering and antioxidant activities to justify their Nigerian ethnomedicinal usage. Leaf methanolic extracts $(100,200$ and $400 \mathrm{mg} / \mathrm{kg}$, p.o.) were assayed in normal, glucose-and alloxan -induced diabetic rats, while 1,1,-diphenyl-2-picrylhydrazyl, total antioxidant capacity, ferric reducing antioxidant power and hydroxyl radical scavenging tests were used for their antioxidant activity. Effects of n-hexane, dichloromethane, ethylacetate and aqueous partition fractions of the three most active anti-hyperglycaemic extracts were also tested in glucose-loaded rats. In normoglycaemic rats, all extracts generally lacked activity, while with glucose-loaded rats, only O. subscorpioidea (200mg/kg) and C. patens $(400 \mathrm{mg} / \mathrm{kg})$ at $1 \mathrm{~h}$ and 0 . subscorpioidea (200, 400 $\mathrm{mg} / \mathrm{kg}$ ) and $C$. patens $(400 \mathrm{mg} / \mathrm{kg})$ at $2-4$ hours gave lowered $(\mathrm{p}<0.05)$ blood glucose levels than glibenclamide $(5 \mathrm{mg} / \mathrm{kg})$, while activity of $\mathrm{H}$. opposita and $P$. zeylanica $(200 \mathrm{mg} / \mathrm{kg})$ were only comparable to glibenclamide. When daily fed for fourteen days to alloxan-induced diabetic rats, all extracts, at their most active doses, gave significantly higher activity than glibenclamide. Olax subscorpioidea leaf extract had the highest hyperglycaemic-lowering and least antioxidant activities. Highest antioxidant activity of $\mathrm{H}$. opposita may suggest some contribution of antioxidant property to its hyperglycaemic-lowering activity. The glucose-lowering and insulinotropic constituents of $O$. subscorpioidea, $H$. opposita and $C$. patens should be concentrated in their aqueous, aqueous and dichloromethane fractions, respectively. Anti-hyperglycaemic ethnomedicinal use of these plants was justified and $\mathrm{H}$. opposita has additional antioxidant property.
\end{abstract}

Keywords: Key words: Antioxidant activity, Diabetes mellitus, Nigerian anti-diabetic plants

\section{INTRODUCTION}

Diabetes mellitus is a chronic disease of metabolic disorders of carbohydrate, protein and fat that is due to relative or absolute lack of insulin and various degrees of insulin resistance
(Olaniyi, 2003, Adebajo et al., 2007, 2013a). Currently, it affects about 16 million people in the United States, 285 million worldwide and is projected to rise to about 400 million in 2030 , especially in urban populations of the 
developing countries (Adebajo et al., 2013b; Roglic et al., 2004). The disease has no cure while the available synthetic hypoglycaemic drugs have serious adverse effects, thereby justifying the increased investigations of plants with anti-diabetic ethnomedicinal use (Adebajo et al., 2009, 2013a, Olayiwola et al., 2004, Rang et al., 2007).

Normal metabolic processes in the body generate free radicals known as reactive oxygen species (ROS), such as hydroperoxyl $\left(\mathrm{HO}_{2}{ }^{\circ}\right)$, hydrogen peroxide $\left(\mathrm{H}_{2} \mathrm{O}_{2}\right)$, singlet oxygen $\left(\mathrm{O}^{\circ}\right)$, triplet oxygen $\left(\mathrm{O}_{3}{ }^{\circ}\right)$ and superoxide $\left(\mathrm{O}_{2}^{-}\right)$ions, which lead to oxidative stress (Adebajo et al., 2013a, Kumar, 2011, Somsuvra et al., 2012). Generated ROS are shown to be involved in the pathogenesis of diabetes and their scavengers are effective in preventing experimental diabetes in animal models as well as reduction in the severity of types 1 and 2 diabetic complications (Jeanette et al., 2005). Oxidative stress is also implicated in a wide range of chronic and acute diseases, including Alzheimer, cancer and cardiovascular diseases (Adebajo et al., 2013a, Akinwunmi and Oyedapo, 2013). Antioxidants, both enzymatic and non-enzymatic, function as free radical scavengers, reducing agents and quenchers of singlet oxygen formation, thereby limiting oxidative damage to biological molecules (Kottai et al., 2011).

Dioscoreophyllum cumminsii is indigenous to tropical West Africa and its tubers, which resemble small yams, are eaten by some tribes in Africa (Inglett, 1975). Hoslundia opposita (Iwu, 1993, Odugbemi, 2008) and Plumbago zeylanica are tropical perennial shrubs (Kiritikar and Basu, 1993) growing in Nigeria, while Olax subscorpioidea is widely distributed in Nigeria, Zaire and Senegal (Burkill, 1985). Cleistopholis patens is a tree of southern Nigeria (Udem et al, 2011). They are used in Nigeria and other African countries in the management of diabetes (Odugbemi, 2008, Olagunju et al., 2006, Gbolade, 2009, Koffi et al., 2009) with other folkloric uses in treating fevers, infective hepatitis, malaria, heart troubles and obesity (Odugbemi, 2008, Akah and Odo, 2010, Chiu and Chang, 2003, Okoli et al., 2007). Their antiinfective, anti-oxidant, anti-malarial, hepatoprotective, hypolipidaemic, and other pharmacological actions may additionally help diabetes sufferers of Africa (Boyom et al., 2011, Adefegha and Oboh, 2011). Therefore, leaf methanolic extracts of these five plants were assayed for their hypoglycaemic, hyperglycaemic-lowering, and anti-oxidant activities to confirm their anti-hyperglycaemic activity and thereby justify their folkloric antidiabetic usage. Also, hyperglycaemic-lowering activities of various solvent fractions of three active extracts were evaluated to determine the candidacy of these plants in antidiabetic drug development.

\section{MATERIALS AND METHODS}

Chemicals, equipment and instrumentation UV Spectrophotometer (Model M107, SpectronicCamspec Ltd, U.K.), Vortex Genie rotamixer (K-550-GE model, Vortex-Genie accessories, U.S.A.), CareSens ${ }^{\mathrm{TM}} \mathrm{N}$ Glucometer (model PGA 1E3028 REV3, i- SENS, Inc., Korea) with CareSens ${ }^{\mathrm{TM}}$ test strips (i- SENS, Inc., Korea), ammonium molybdate, ascorbic acid, sodium acetate, 2,4,6-tripyridyl-s-triazine (TPTZ), trolox, alloxan monohydrate and 1,1, diphenyl-1-picrylhydrazyl radical (SigmaAldrich Co. LLC, U.S.A.).

Plant materials, extraction and solvent partitioning

The leaves of Hoslundia opposita Vahl. (Lamiaceae), Dioscoreophyllum cumminsii Diels. (Menispermaceae), Plumbago zeylanica L. (Plumbaginaceae), Olax subscorpioidea Oliv. (Olacaceae) and Cleistopholis patens (Benth.) Engl. \& Diels. (Annonaceae) were collected from the Campus of Obafemi Awolowo University (O.A.U.), Ile-Ife, Nigeria after authentication by Prof. H.C. Illoh, Botany department, Faculty of Science, O.A.U., Ile-Ife. Their respective voucher specimens, IFE $16470,16471,16769,16517,16472$, were deposited in IFE Herbarium, Botany department, O.A.U, Ile-Ife. The leaves were air dried, powdered and $1.0 \mathrm{~kg}$ of the powdered materials were separately extracted with methanol at room temperature. The extracts were concentrated in-vacuo to give their corresponding methanolic extracts, coded HOL, DCL, PZL, OSL and CPL with the yields of $18.2, \quad 8.5, \quad 10.8, \quad 11.0$ and $8.0 \% \quad \% / w$, respectively. 
Methanolic leaf extracts of $O$. subscorpioidea (OSL), C. patens (CPL) and H. opposita (HOL) that were the three most active extracts were separately suspended in water, successively partitioned with $n$-hexane, dichloromethane and ethyl acetate and concentrated in vacuo to obtain their corresponding $n$-hexane OSLB $_{1}$, $\left.\mathrm{CPLB}_{1}, \mathrm{HOLB}_{1}\right)$, dichloromethane (OSLB $_{2}$, $\left.\mathrm{CPLB}_{2}, \mathrm{HOLB}_{2}\right)$, ethylacetate $\left(\mathrm{OSLB}_{3}, \mathrm{CPLB}_{3}\right.$, $\left.\mathrm{HOLB}_{3}\right)$ and aqueous $\left(\mathrm{OSLB}_{4}, \mathrm{CPLB}_{4}\right.$, $\mathrm{HOLB}_{4}$ ) fractions.

\section{Animals}

Healthy Wistar albino rats of either sex (210 g, average weight), bred under standard conditions (temp. $27 \pm 3^{\circ} \mathrm{C}$, relative humidity $65 \%$, natural $12 \mathrm{~h}$ day-night) and housed in different cages in the animal house, Department of Pharmacology, Faculty of Pharmacy, O.A.U., IleIfe, Nigeria were used for the experiments. They were acclimatized for at least 5 days before commencement of the experiments and fed on a standard pellet diet (Bendel Feeds, Benin, Nigeria), with water given ad libitum. All animal experiments conformed to the Guide for the Care and Use of Laboratory Animals published by the National Academies Press (Committee for the Update of the Guide for the Care and Use of Laboratory Animals, 2011).

\section{Anti-hyperglycaemic studies of the extracts In normal and glucose-loaded rats}

Groups of five overnight-fasted $(24 \mathrm{~h})$ normal rats were ingested (p.o.) with either $1 \%$ Tween 80 in normal saline (negative control), or methanolic extracts $(100,200,400 \mathrm{mg} / \mathrm{kg})$ of the five plants, or glibenclamide $(5 \mathrm{mg} / \mathrm{kg}$, positive control). Also, glucose $(10 \mathrm{~g} / \mathrm{kg}$, p.o. $)$ was given to 24 hour fasted normal rats and those that were hyperglycaemic [blood glucose level $\geq$ $7.0 \mathrm{mmol} / \mathrm{L}(126 \mathrm{mg} / \mathrm{dL})]$ after 0.5 hour $\left(\mathrm{T}_{\mathrm{o}}\right)$ were selected and divided into groups of five and administered (p.o.) with extracts $(100,200$, $400 \mathrm{mg} / \mathrm{kg}$ ) or positive or negative controls. Also, glucose-lowering activities of the partition fractions were similarly assayed at the doses of the extracts that gave the highest activity. At 0.0, 0.5, 1.0, 2.0 and 4.0 hours after administration of the test agents, a drop of blood that was taken from the tip of the tail of each rat was dropped onto a glucometer strip and the blood glucose level was read directly from the glucometer. The blood glucose levels at $0.0 \mathrm{~h}\left(\mathrm{~T}_{\mathrm{o}}\right)$ were taken as $100 \%$, while those at other times were expressed as percentages of these values (Adebajo et al., 2007, 2009, 2013a, 2013b).

\section{In alloxanised rats}

Groups of rats were injected (i.p.) with 150 $\mathrm{mg} / \mathrm{kg}$ of alloxan monohydrate dissolved in normal saline (Ojezele and Abatan, 2011). For the next 6 days, they were fed and water was given ad libitum. Rats with fasting (24 hour) blood glucose levels $\geq 11.0 \mathrm{mmol} / \mathrm{L}(200 \mathrm{mg} /$ $\mathrm{dL}$ ) that were considered diabetic, were selected and divided into groups of 5 rats each, which were daily administered for 14 days with the doses of the extracts that gave the highest activity, or positive, or negative controls. Their blood glucose levels were determined and recorded on 1, 4, 7, 10 and 14 days after administration of test agents, as given above (Ojezele and Abatan, 2011).

\section{Antioxidant assays}

1,1-diphenyl-2-dipicrylhydrazyl (DPPH) radical scavenging assay

The DPPH Radical Scavenging Activity was determined using the standard method earlier reported and $l$-ascorbic acid was the reference standard (Adebajo et al., 2013a, BrandWilliams et al., 1995).

\section{Ferric reducing antioxidant power (FRAP)} assay

This assay was performed by slight modifications of the described Benzie and Strain (1999) method and the antioxidant activity was presented as Trolox equivalents as given in Adebajo et al. (2013a).

\section{Total antioxidant capacity (TAC) assay}

The TAC assay was done following the prescribed method (Prieto et al., 1999, Adebajo et al., 2013a) and the results were expressed as ascorbic acid equivalents (AAE) $(\mu \mathrm{moL} / \mathrm{g})$.

\section{Hydroxyl radical scavenging activity (HRSA) assay}

The HRSA of the test extracts was evaluated by modification of a described method (FerrerSueta and Radi, 2009). The experiments were 
carried out in triplicates and all reagents for this experiment were freshly prepared. A $10 \mu \mathrm{L}$ aliquot of test sample or standard was mixed with $990 \mu \mathrm{L}$ of reaction buffer containing $100 \mathrm{mM}$ phosphate buffer ( $\mathrm{pH} 7.4$ ), 3.6mM sodium benzoate, $145 \mu \mathrm{M}$ EDTA, $140 \mu \mathrm{M} \mathrm{Fe}(\mathrm{NH} 4)_{2} \mathrm{SO}_{4}$, and $3.6 \mathrm{mM} \mathrm{H}_{2} \mathrm{O}_{2}$. The reaction mixture was incubated at $37^{\circ} \mathrm{C}$ for $1 \mathrm{~h}$ after which $1 \mathrm{~mL}$ of $20 \%$ acetic acid and $1 \mathrm{~mL}$ of $0.8 \%$ thiobarbituric acid, dissolved in $50 \mathrm{mM} \mathrm{NaOH}$, was added. The new mixture was thereafter incubated for $30 \mathrm{~min}$ at $80^{\circ} \mathrm{C}$ and cooled rapidly in an ice bath. The absorbance of the sample was measured at $532 \mathrm{~nm}$ and the percent HRSA was calculated. Trolox in the concentration range of 50 $-250 \mu \mathrm{M}$ was used as standard for the calibration curve and from the linearity equation, concentration of sample that produced same absorbance as $1 \mathrm{mM}$ of Trolox (mM Trolox equivalent) was determined.

\section{STATISTICAL ANALYSIS}

Data represent mean \pm SEM and $n=5$ for animals in the group. They were analysed with One Way Analysis of Variance (ANOVA), followed by Bonferroni t-test or Student-Newman-Keuls post-hoc tests, using GraphPad ${ }^{\circledR}$ Instat, version 5.0 (GraphPad Software Inc., San Diego, USA). $\mathrm{P}<0.05$ was considered significant.

\section{RESULTS AND DISCUSSION}

The mechanisms of action of glibenclamide are early extra-pancreatic and late insulin stimulating effects (Luzi and Pozza, 1997). Therefore, profile of activity that is similar to that of glibenclamide with glucose-loaded rat model allows a guess of similar mechanisms of action of plant extracts/fractions/test agents (Adebajo et al., 2013a, 2013b, Murray et al., 2006, Verspohl, 2002). Earlier, using glucose-loaded rat model, hyperglycaemic-lowering (antihyperglycaemic) activity of plants were corroborated by their in vivo and in vitro insulinotropic activities (Adebajo et al., 2007, 2009, 2013a, 2013b, Alade et al., 2011). It was therefore suggested that the use of glibenclamide and other insulin stimulatory drugs as standard drugs in glucose-loaded rat studies, may help in establishing plants with insulin stimulating activity that could be used in human type 2 diabetes resulting from insufficient insulin production (Adebajo et al., 2013a, 2013b, Murray et al., 2006, Verspohl, 2002). Alloxan-induced diabetic rat model was additionally used in this study to further confirm the hyperglycaemialowering (anti-diabetic) activity of the extracts/ fractions in a true diabetic state (Gupta et al., 2011). Also, the extracts were evaluated for antioxidant activity to determine any contribution of this activity to their antidiabetic effects (Adebajo et al., 2013a, 2013b).

\section{Hypoglycaemic effect of the extracts}

Glibenclamide $(5 \mathrm{mg} / \mathrm{kg})$ gave a non-time dependent $41,54,61$ and $44 \%$ blood glucose reductions at $0.5,1,2$ and 4 hours, respectively in normoglycaemic rats that were significantly ( $p$ $<0.05$ ) higher at all time points than those elicited by 100,200 , and $400 \mathrm{mg} / \mathrm{kg}$ of the extracts (Table 1). This may confirm the documented hypoglycaemic side effect of glibenclamide, a standard anti-diabetic drug (Luzi and Pozza, 1997). Compared to that of glibenclamide, hypoglycaemic activities of the extracts were nondose dependent and significantly $(p<0.05)$ reduced (Table 1). These may suggest that they are likely safe and may not precipitate hypoglycaemia when used by non-diabetic human or animal subjects. Similarly, respective leaf aqueous and methanolic extracts of Nigerian antidiabetic Nauclea latifolia and Eugenia uniflora that were proven to possess antihyperglycaemic activity, were also reported safe for non-diabetic humans because they lacked significant hypoglycaemic effect in normal rats (Adebajo et al., 2013a, 2013b; Gidado et al., 2005).

\section{Hyperglycaemic-lowering effect of the ex- tracts in glucose-loaded rats}

The significant time dependent reductions, up to the fourth hour (Table 2), in blood glucose levels of the negative-control glucose-induced hyperglycaemic rat group was due to the homeostatic regulatory mechanism and confirmed that their pancreases were functioning well (Adebajo et al., 2013a, 2013b; Kar et al., 1999). Only the leaf extracts of $O$. subscorpioidea $(100$ $-400 \mathrm{mg} / \mathrm{kg})$, H. opposita $(200 \mathrm{mg} / \mathrm{kg})$, C. patens $(400 \mathrm{mg} / \mathrm{kg})$, P. zeylanica $(100,200 \mathrm{mg} / \mathrm{kg})$, and D. cumminsii $(200 \mathrm{mg} / \mathrm{kg})$ demonstrated an activity profile that was time dependent and maximal at the fourth hour, similar to $5 \mathrm{mg} / \mathrm{kg}$ of Glibenclamide (Table 2). 
Evaluation of five Nigerian antidiabetic plants... 75

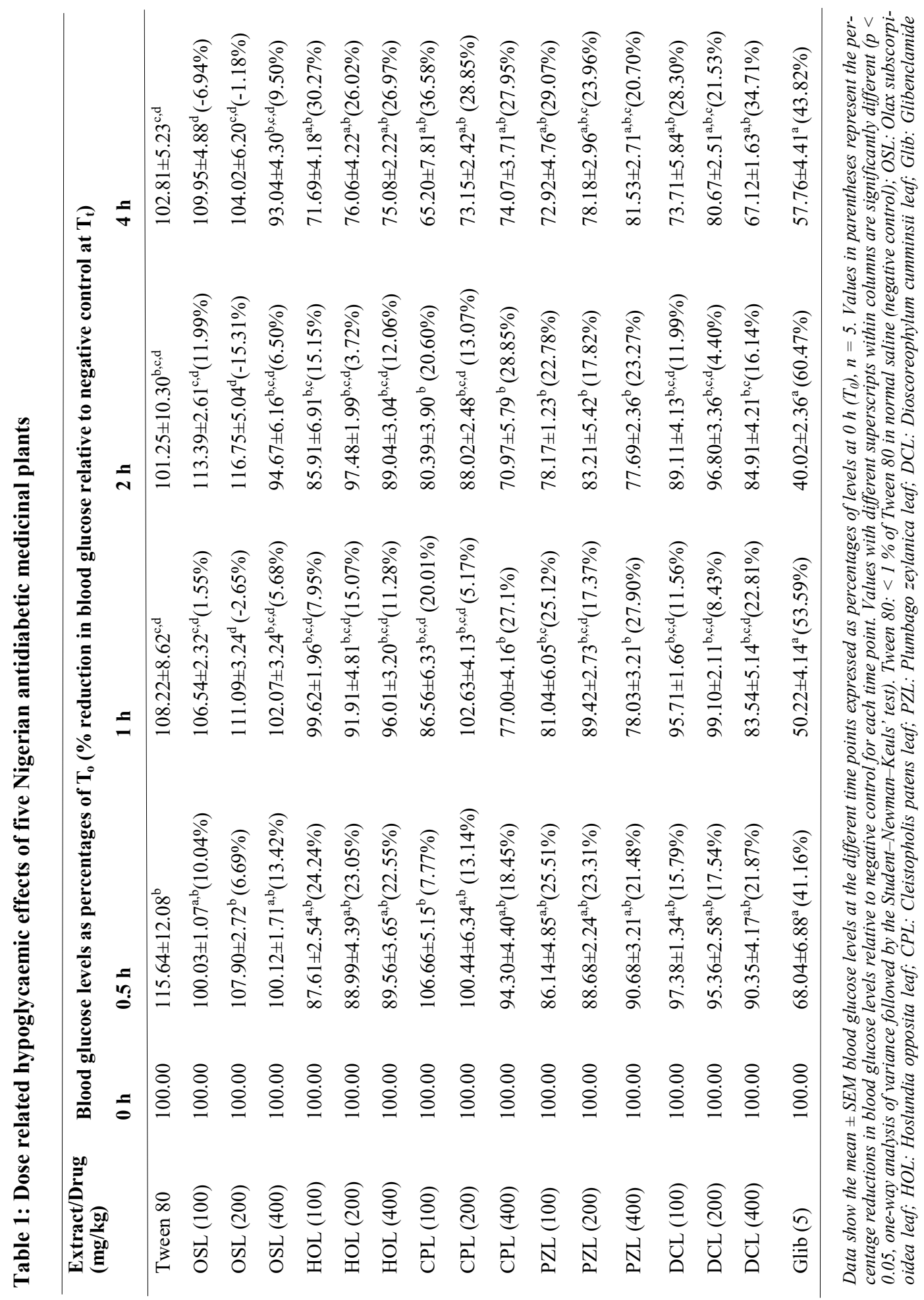




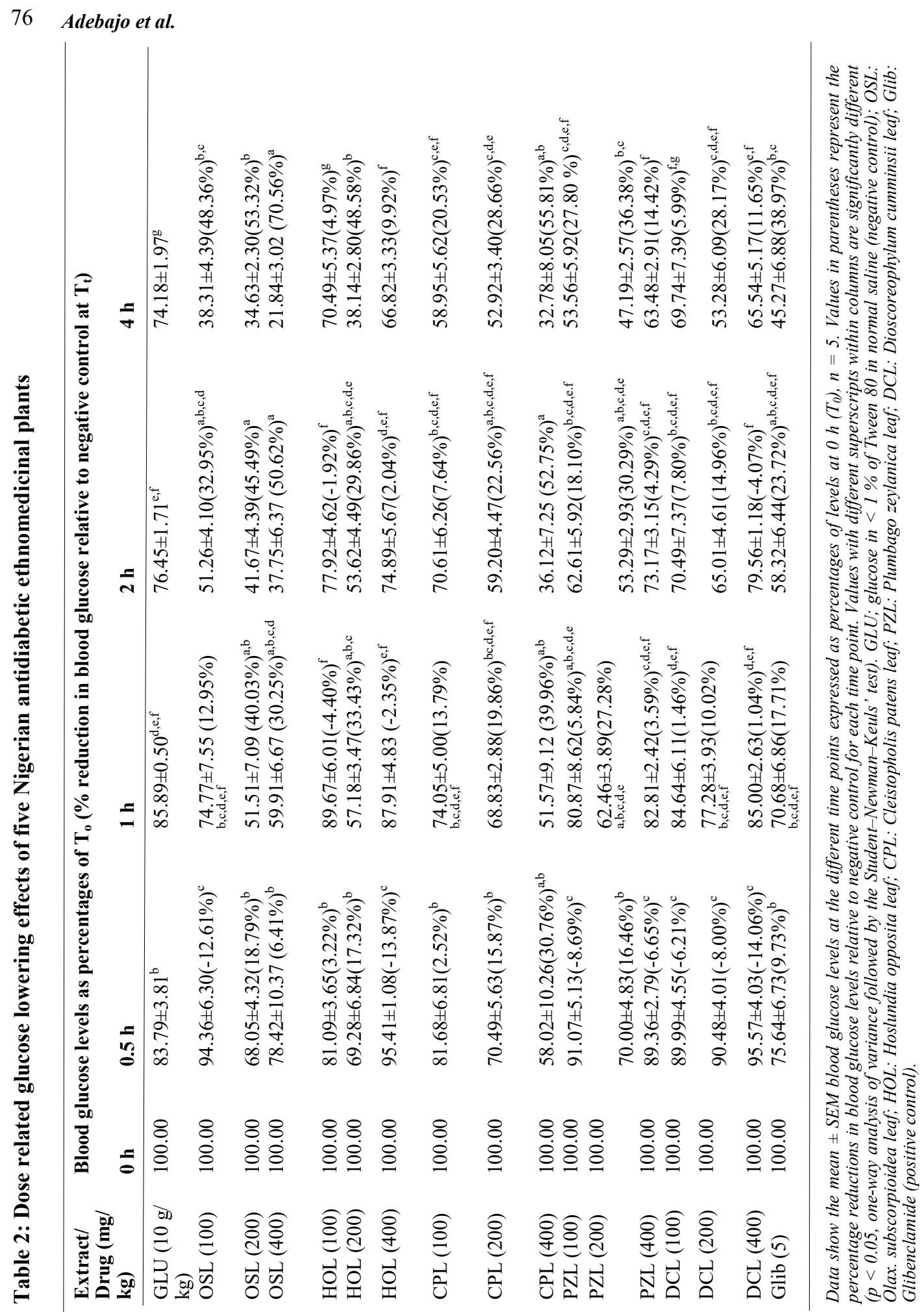


Evaluation of five Nigerian antidiabetic plants... 77

The $>30 \%$ blood glucose reductions given by O. subscorpioidea $(200,400 \mathrm{mg} / \mathrm{kg})$, H. opposita $(200 \mathrm{mg} / \mathrm{kg})$ and C. patens $(400 \mathrm{mg} / \mathrm{kg})$ at 1 $\mathrm{h}$, which were significantly higher than $18 \%$ elicited by glibenclamide, may suggest additional extrapancreatic activity for these plant extracts (Adebajo et al., 2009). Also, the hyperglycaemia-lowering activities demonstrated by $O$. subscorpioidea $(100-400 \mathrm{mg} / \mathrm{kg})$ and $C$. patens $(400 \mathrm{mg} / \mathrm{kg})$ at 2 and 4 hours were significantly higher than that given by glibenclamide, while those of $H$. opposita and P. zeylanica $(200 \mathrm{mg} / \mathrm{kg})$ at these hours were comparable $(\mathrm{p}>0.05)$ to that of glibenclamide (Table 2). Similar to glibenclamide, the highest activity of the extract was at 4 hour and this similar profile of activity has been reported to be due to early and mild extra-pancreatic, late and major insulinotropic activities of glibenclamide (Adebajo et al., 2009; 2013b; Luzi and Pozza, 1997; Luzi and DeFronzo, 1989).

Hence, suggestion of stimulation of insulin release by these plant extracts may be the scientific justification of their anti-hyperglycaemic activity and probably explain their ethnomedicinal antidiabetic usage in diabetes occasioned by insufficient insulin production. Similarly, extracts of Gongronema latifolium, E. uniflora, Stachytarpheta cayennensis, Jatropha tanjorensis and Clausena lansium with insulin stimulation properties have been suggested as herbal drugs for managing this type of diabetes (Adebajo et al., 2007, 2009, 2013a, 2013b; Olayiwola et al., 2004).

Doses of 100 and $400 \mathrm{mg} / \mathrm{kg}$ of H. opposita and $D$. cumminsii, and $P$. zeylanica $(400 \mathrm{mg} / \mathrm{kg})$ lacked hyperglycaemic-lowering activity at all hours, while activities of $100,200 \mathrm{mg} / \mathrm{kg}$ of $C$. patens and $P$. zeylanica, and D. cumminsii $(200$ $\mathrm{mg} / \mathrm{kg}$ ) were weak to moderate (Table 2). Therefore, O. subscorpioidea leaf extract was the most active and the order of hyperglycaemic-lowering activity of the extracts, at their most effective doses, was $O$. subscorpioidea $>$ C. patens $>H$. opposita $>P$. zeylanica $=$ glibenclamide $>$ D. cumminsii (Table 2).
Hyperglycaemic-lowering effect of the extracts in alloxanised rats

The persistent hyperglycaemia in the negative control group of alloxanised rats showed that they were diabetic (Ojezele and Abatan, 2011). Daily (14 days) oral administration of the most effective (hyperglycaemic-lowering) doses of the extracts' (Table 2) to these rats produced blood glucose-lowering (antidiabetic) effects that were significantly better than that of glibenclamide (Table 3). Also, similar to glibenclamide, the hyperglycaemiclowering activities of the extracts were maximal at the $14^{\text {th }}$ day (Table 3 ).

Moreover, the activity of all the extracts were comparable at days 10 and 14 while at days 4 and 7 the order was $O$. subscorpioidea $>C$. patens $=H$. opposita $>$ P. zeylanica $=D$. cumminsii $>$ glibenclamide and $O$. subscorpioidea $>$ H. opposita $=C$. patens $=P$. zeylanica $>D$. cumminsii $>$ glibenclamide, respectively (Table 3 ). Therefore, results of Tables 2 and 3 agreed that $O$. subscorpioidea leaf extract was the most active hyperglycaemic-lowering extract in both glucose-loaded and alloxan-diabetic rat models.

Methanolic extracts of $S$. cayennensis, J. tanjorensis and Bauhinia monandra that had similar profile of activity as glibenclamide and gave significant hyperglycaemic-lowering (antihyperglycaemic) activities in glucose-loaded and alloxan-diabetic rat models have been shown to have in vivo and in vitro insulin releasing activities (Adebajo et al., 2007, Alade et al., 2011, 2012, Olayiwola et al., 2004). Insulin release has been reported as a major mechanism of action of glibenclamide (Luzi and Pozza, 1997). These five plants having significant hyperglycaemic-lowering activities and similar profile of activity as glibenclamide in these two rat models (Tables 2, 3), may also be insulinrelease stimulating and therefore provides a justification of their continued folkloric utilisation in managing diabetes (Adebajo et al., 2007, Alade et al., 2011, 2012, Olayiwola et al., 2004).

Furthermore, $81 \%$ activity was elicited by $P$. zeylanica leaf extract when given for 14 days to alloxan-induced diabetic rats in this study (Table 3 ) while only $48 \%$ activity was reported 
for its root extract $(200 \mathrm{mg} / \mathrm{kg})$ given for over 42 days to streptozotocin-induced diabetic rats (Muftah et al., 2010). This may indicate that the leaf may be a better anti-hyperglycaemic herbal drug. Alloxan and streptozotocin are usually the diabetogenic agents used to induce diabetes in the experimental animals (Jeanette et al., 2005, Szkudelski, 2001). They both produce non-definite diabetic states in animals, as the state readily changes from mild to moderate to severe diabetes. Hence, the real state, which is in-between types I and II, is difficult to ascertain or classify (Verspohl, 2002). Alloxan acts by releasing highly reactive free radicals that damage the DNA of $\beta$-cells and ultimately resulting in cell death. High mortality in rats, ketosis in animals due to free fatty acid generation, non-selectivity of action and reversibility of the induced diabetes are the disadvantages of using alloxan in the induction of diabetes (Gupta, 2004). Streptozotocin also causes $\beta$ cell death by the formation of free radicals and other mechanisms. Although its action is more selective and has a lower mortality rate than alloxan, it causes liver and kidney damage to the animals with bone marrow depression (Jong et al., 2006).

\section{Antioxidant activities of the extracts}

Since plumbagin has been identified as the antioxidant constituent of $P$. zeylanica (Tilak et al., 2004), this plant was not included in this present antioxidant study. The order of free radical scavenging activity, a preliminary antioxidant activity, was vitamin $\mathrm{C}=H$. opposita $>$ D. cumminsii $=C$. patens $>O$. subscorpoidea . Using FRAP and TAC assays, order of their antioxidant capacities was similar and shown to be $H$. opposita $=D$. cumminsii $>C$. patens $=$ $O$. subscorpoidea while that of HRSA was $D$. cumminsii $=H$. opposita $=C$. patens $>O$. subscorpoidea (Table 4). Hence, H. opposita and D. cumminsii had the highest antioxidant activity while $C$. patens and O. subscorpoidea were the least active.

Generated ROS were implicated in the pathogenesis of diabetes and their scavengers were reported to be effective in preventing experimental diabetes in animal models as well as reduced the severity of types 1 and 2 diabetic complications (Jeanette et al., 2005). Momordi- 
Evaluation of five Nigerian antidiabetic plants... 79

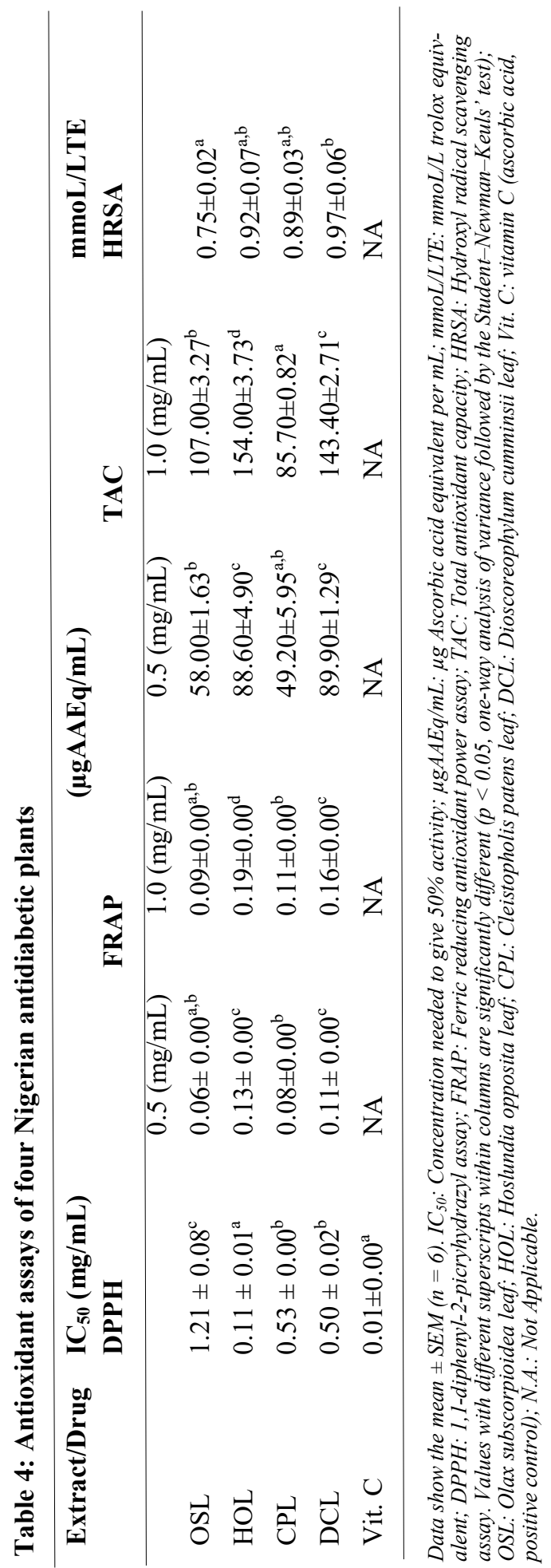

ca charantia, Rosmarinus officinalis and $S$. cayennensis are some of the medicinal plants often used in the management of diabetic syndromes that also possess antioxidant properties (Adebajo et al., 2007; Sathishsekar and Subramanian, 2005; Khalil et al., 2012). Contribution of antioxidant property to anti-diabetic activity of plants has been scientifically demonstrated in E. uniflora (Adebajo et al., 2013a).

Therefore, the present demonstration of high glucose-lowering activity (Tables 2, 3) and the highest anti-oxidant activity (Table 4) by $H$. opposita leaf would be corroborating this additional property in plants that are used ethnomedicinally in Nigeria to manage diabetes. Hence, only $H$. opposita leaf extract may show that anti -oxidant property, which will scavenge ROS generated in diabetic conditions, should contribute to its anti-diabetic activity (Adebajo et al., 2013a; Jeanette et al., 2005).

\section{Hyperglycaemic-lowering effect of the parti- tion fractions}

Generally, the $n$-hexane $\left(\mathrm{OSLB}_{1}\right)$, dichloromethane $\left(\mathrm{OSLB}_{2}\right)$ and ethyl acetate $\left(\mathrm{OSLB}_{3}\right)$ partition fractions of $O$. subscorpioidea methanolic extract (OSL) were inactive. However, $\mathrm{OSLB}_{3}$ gave a $15 \%$ hyperglycaemia-lowering activity at 4 hour that was comparable to that of OSL. Activities of OSL, its aqueous partition fraction $\left(\mathrm{OSLB}_{4}\right)$ and glibenclamide were comparable at 0.5 hour while that of the mother extract (OSL) was comparable to that of glibenclamide at 1.0 hour but significantly higher than those of glibenclamide and the aqueous fraction $\left(\mathrm{OSLB}_{4}\right)$ at 2-4 hours. Antihyperglycaemic activity of $\mathrm{OSLB}_{4}$ and glibenclamide was comparable at all time points (Table 5).

These indicated that the main hyperglycaemiclowering constituents of $O$. subscorpioidea would be concentrated in this polar fraction and have similar insulin stimulatory mechanism of action of glibenclamide (Luzi and Pozza, 1997). However, some ethylacetate $\left(\mathrm{OSLB}_{3}\right)$ constituents should make little contribution to this activity. Activities of the $H$. opposita extract (HOL) and its most active aqueous partition fraction $\left(\mathrm{HOLB}_{4}\right)$ were comparable with that of glibenclamide at all hours, while that of HOL 


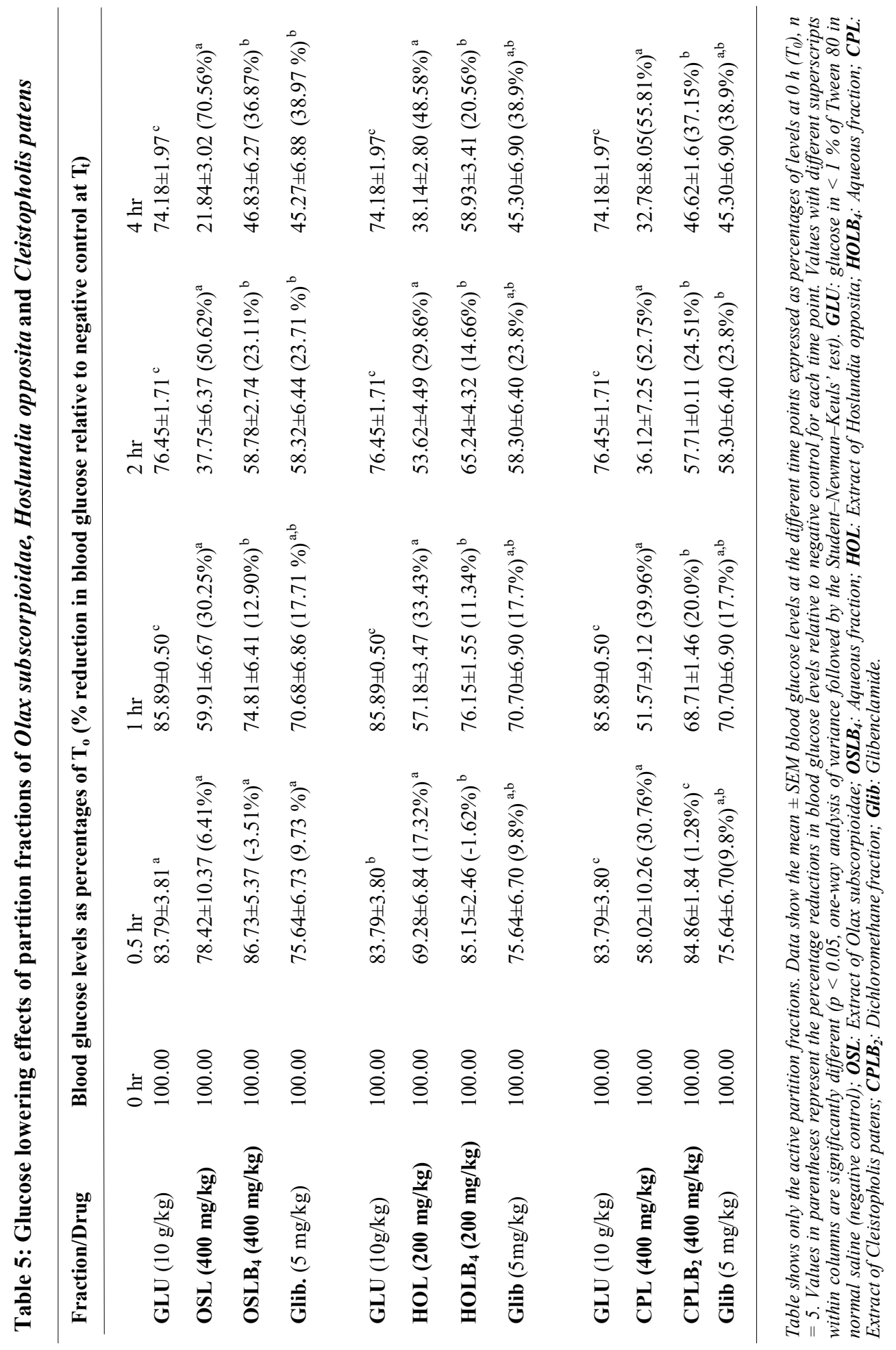


was significantly higher than that of $\mathrm{HOLB}_{4}$ at all hours (Table 5). Similarly, polar constituents with insulin stimulatory property would mainly be responsible for the anti-hyperglycaemic activity of $H$. opposita, while some $14 \%$ activity at 4 hour by its $n$-hexane $\left(\mathrm{HOLB}_{1}\right)$ fraction should make some contributions to this activity (Adebajo et al., 2013a).

Conversely, the chloroform $\left(\mathrm{CPLB}_{2}\right)$ fraction of $C$. patens extract (CPL) was the most active fraction, and at all time points, its activity was lower than that of its mother extract and comparable to that of glibenclamide (Table 5). Thus, it gave the hope of mediumly non-polar insulinotropic compounds as its main active constituents. The higher activity of the methanolic extracts (OSL, HOL and CPL) of $O$. subscorpioidea, H. opposita and C. patens suggested that a simple soaking of these Nigerian ethnomedicinal plants in local alcohol (dry gin) would be better anti-hyperglycaemic agents, especially in Nigerian folkloric medicine (Sofowora, 2008). Hence, further efforts at their purification would not add to the pharmacological activity of these three plants (Adebajo et al., 2013a). However, isolation and structural elucidation of their anti-diabetic constituents is still imperative for formulating quality assurance protocols in the manufacture of these herbal drugs as well as knowing the constituents to be assayed in their commerce (Adebajo et al., 2013b).

In orthodox drugs, there is a limit of the active constituents expected before they get into the market (B.P., 1980). Pyrethrum Extract BP contains $24.5-25.5 \%$ of pyrethrins and not less than $50 \%$ of pyrethrin I and II (Trease and Evans, 2002, 2009). Also, qualitative and quantitative variations have been reported in collected plants with the attendant variation in activity (Trease and Evans, 2002). Furthermore, identification of artemisinin as the antimalarial constituent of Artemisia annua turned the once Chinese traditional medicine into an orthodox drug (Trease and Evans, 2002, Sofowora, 2008), while analogues of pyrethrins with activity that was $>1,000$ times that of pyrethrin I and lower toxicity, are now available in the markets (Trease and Evans, 2009). Hence, the authors are advocating the use of African herbs such as these three Nigerian plants, once proven safe, as well as continuing the investigations to identify their active constituents (Adebajo et al., 2013a,b).

\section{CONCLUSION}

The results of this study showed that the extracts of these five Nigerian ethnomedicinal plants used in the management of diabetes may be safe as they did not precipitate hypoglycaemia in non-diabetic subjects. The high glucoselowering activities demonstrated by these plants, especially that of $O$. subscorpioidae, in both glucose- and alloxan-induced hyperglycaemic rats, have justified their antidiabetic folkloric claims. There is the possibility that antioxidant property may contribute to the hyperglycaemic-lowering activity demonstrated by $H$. opposita. The anti-hyperglycaemic constituents of $O$. subscorpioidae and $H$. opposita are mostly concentrated in the aqueous fraction while those of $C$. patens are in the dichloromethane fraction.

\section{ACKNOWLEDGEMENTS}

One of the authors, MDA, thank the Council, Obafemi Awolowo University, Ile-Ife for sponsorship of his $\mathrm{Ph} . \mathrm{D}$. degree under the in-service training programme.

\section{DISCLOSURE}

The authors declare no conflict of interest.

\section{REFERENCES}

Adebajo, A.C., Ayoola, M.D., Obagbemi, O.R., Obuotor, E.M., Ogunsina, M.O. and Verspohl, E. J. (2013a). Antihyperglycaemic and antioxidant activities of Eugenia uniflora leaf: evaluation of ethnomedical claims IV. Ife Journal of Science and Technology, 1: 118.

Adebajo, A.C., Ayoola, M.D., Odediran, S.A., Aladesanmi, A.J., Schmidt, T.J. and Verspohl, E.J. (2013b). Evaluation of ethnomedical claims III: antihyperglycemic activities of Gongronema latifolium root and stem. Journal of Diabetes, 5: 336-43.

Adebajo, A.C., Iwalewa, E.O., Obuotor, E.M., Ibikunle, G.F., Omisore, N.O., Adewunmi, C.O., Obaparusi, O.O., Klaes, M., Adetogun, 
G.E., Schmidt T.J. and Verspohl, E.J. (2009). Pharmacological properties of the extract and some isolated compounds of Clausena lansium stem bark: anti-trichomonal, antidiabetic, anti-inflammatory, hepatoprotective and antioxidant effects. Journal of Ethnopharmacology, 122: 10-19.

Adebajo, A.C., Olawode, E.O., Omobuwajo, O.R., Adesanya, S.A., Begrow, F., Elkhawad, A., Akanmu, M.A., Edrada, R., Proksch, P., Schmidt, T.J., Klaes, M. and Verspohl, E.J. (2007). Hypoglycaemic constituents of Stachytarpheta cayennensis leaf. Planta Medica, 73(3): 241-50.

Adefegha, S.A. and Oboh, G. (2011). Cooking enhances the antioxidant properties of some tropical green leafy vegetables. African Journal of Biotechnology, 10: 632-39.

Akah, P.A and Odo, C.I. (2010). Hepatoprotective effect of the solvent fractions of the stem of Hoslundia opposita Vahl. (Lamiaceae) against carbon tetrachloride and paracetamol induced liver damage in rats. International Journal of Green Pharmacy, 4: 54-58.

Akinwunmi, K.F and Oyedapo, O.O. (2013). Evaluation of antioxidant potentials of Monodora myristica (Gaertn) dunel seeds. African Journal of Food Science, 7: 317-24.

Alade, G.O., Adebajo, A.C., Omobuwajo, O.R., Proksch, P and Verspohl, E.O. (2012). Quercetin, a minor constituent of the antihyperglycaemic fraction of Bauhinia monandra leaf.. Journal of Diabetes, 4: 439-41.

Alade, G.O., Omobuwajo, O.R., Adebajo, C.A and Verspohl, E.J. (2011). Evaluation of the hypoglycaemic activity of Bauhinia monandra leaf in alloxan-diabetic rats and INS-1 insulin cells. Journal of Chemical and Pharmaceutical Research, 3: 506-21.

Benzie, F.F. and Strain, J.J. (1999). Ferric reducing/antioxidant power assay: direct measure of total antioxidant activity of biological fluids and modified version for simultaneous measurement of total antioxidant power and ascorbic acid concentration. Methods in Enzymology, 299: 15-23.

Boyom, F.F., Ngouana V., Kemgne, E.A., Menut, P.H., Gut, J., Rosenthal, P.J. (2011). Antiplasmodial volatile extracts from Cleistopholis patens Engler \& Diels and Uvariastrum pierreanum Engl. (Engl. \& Diels) (Annonaceae) growing in Cameroon. Parasitology Research, 108(5): 1211-17.

Brand-Williams, W., Cuvelier, M.E. and Berset, C. (1995). Use of a free radical method to evaluate antioxidant activity. $L W T$ - Food Science and Technology, 28: 25-30.

British Pharmacopoeia (1980). Vol.2, University press, Cambridge.

Burkill, H.M. (1985). The Useful Plants of West Tropical Africa, $2^{\text {nd }}$ Edition, Royal Botanic Gardens, Britain, pp. 109-10.

Chiu, N.Y. and Chang, K.H. (2003). The Illustrated Medicinal Plants of Taiwan. $5^{\text {th }}$ Edition, Vol. 4, SMC Publishing Inc., Tarpel: pp. 152-53.

Committee for the Update of the Guide for the Care and Use of Laboratory Animals, Institute for Laboratory Animal Research, Division on Earth and Life Studies, National Research Council of the National Academies. Guide for the Care and Use of Laboratory Animals, $8^{\text {th }}$ edn. The National Academies Press, Washington, DC, 2011.

Ferrer-Sueta, G. and Radi, R. (2009). Chemical biology of peroxynitrite: kinetics, diffusion, and radicals. Chemical Biology, 20: 161-77.

Gbolade, A. A. (2009). Inventory of antidiabetic plants in selected districts of Lagos State, Nigeria. Journal of Ethnopharmacology, 121: 135-39.

Gidado, A., Ameh, D.A. and Atawodi, S.E (2005). Effect of Nauclea latifolia leaves aqueous extracts on blood glucose levels of normal and alloxan induced diabetic rats. African Journal of Biotechnology, 4: 91-93. 
Evaluations of five Nigerian antidiabetic plants... 83

Gupta, S. K. (2004). Drug Screening Methods. JP Medical Publishers Ltd. New Delhi. Pp. 307- 317.

Inglett, G.E. (1975). Protein Sweeteners in the Chemistry and Biochemistry of Plant Proteins. Academic Press, Inc. Limited. London, pp. 7-10.

Iwu, M. (1993). Handbook of African Medicinal Plants. CRP Press, BOCa Raton, Florida, pp. 192.

Jeanette, S.J., Alex, K.H., David, J.R., Adviye, E. (2005). Oxidative stress and the use of antioxidants in diabetes: linking basic science to clinical practice. Cardiovascular Diabetology, 4: 2844-45.

Jong, D. K., Seock, M.K., Bu, I.S., Hae, Y.C., Hong S.K and Sae, K.K. (2006). Antidiabetic activity of SMK001, a poly herbal formula in streptozotocin induced diabetic rats: therapuetic study. Biological and Pharmaceutical Bulletin, 29(3): 477-82.

Kar, A., Choudhary, B.K. and Bandyopadhyay, N.G. (1999). Preliminary studies on the inorganic constituents of some indigenous hypoglycaemic herbs on oral glucose tolerance test. Journal of Ethnopharmacology, 64: 17984.

Khalil, O.A., Ramadan, K.S., Danial, E.N, Alnahdi, H.S. and Ayaz, N.O. (2012). Antidiabetic activity of Rosmarinus officinalis and its relationship with the antioxidant property. African Journal of Pharmacy and Pharmacology, 6: 1031-36.

Kiritikar, K.R. and Basu, B.D. (1993). Indian Medicinal Plants. Shiva Publishers Dehradun, India, pp. 1466-68.

Koffi, N., Édouard, K.K. and Kouassi, K. (2009). Ethnobotanical study of plants used to treat diabetes in traditional medicine by Abbey and Krobou People of Agboville (Côte-d'Ivoire). American Journal of Scientific Research, 4: 45-48.

Kottai, M.A., Shajiselvin, C.D., Soasundaram,
G. (2011). In-vitro antioxidant potential of various extracts from whole plants of $\mathrm{Bau}$ hinia purpurea (Linn.). International Journal of PharmTech. Research, 3: 919-24.

Kumar, S. (2011). Free radicals and antioxidants: Human and food system. Advances in Applied Science Research, 2: 129-35.

Luzi, L. and DeFronzo, R.A. (1989). Effect of loss of first-phase insulin secretion on hepatic glucose production and tissue glucose disposal in humans. American Journal of Physiology, Endocrinology and Metabolism, 257: E241-46.

Luzi, L. and Pozza, G. (1997). Glibenclamide: an old drug with a novel mechanism of action? Acta Diabetologica, 34: 239-44.

Muftah, M.Z., Karthikeyan, S., Viswanathan, S. and Kumar, P.G. (2010). Cause and effect of Plumbago zeylanica root extract on blood glucose and hepatic enzymes in experimental diabetic rats. A frican Journal of Microbiology Research, 4: 2674-77.

Murray, R.K., Granner, D.K. and Rodwell, V.W. (2006). Harper's Illustrated Biochemistry, $27^{\text {th }}$ International Edition, McGraw-Hill Education (Asia), Singapore, pp. 172-75.

Odugbemi, T. (2008). Outlines and Pictures of Medicinal Plants from Nigeria. $2^{\text {nd }}$ Edition, University of Lagos Press, Lagos, pp. 95138.

Ojezele, M.O. and Abatan, O.M. (2011). Hypoglycaemic and coronary risk index (CRI) lowering effects of Bauhinia thoningii in alloxan induced diabetic rats. A frican Health Sciences, 11: 489-93.

Okoli, R.I., Aigbe, O., Ohaju-Obodo, J.O. and Mensah, J.K. (2007). Medicinal herbs used for managing some common ailments among Esan People of Edo State, Nigeria. Pakistan Journal of Nutrition, 6: 490-96.

Olagunju, J.A., Fagbohunka, B.S., Oyedapo, O.O., Abdul, A.I.A. (2006). Effects of an ethanol root extract of Plumbago zeylanica 
Linn. on some serum parameters of the rats. Phytotherapy Research, 13:346-48.

Olaniyi, A.A. (2003). Essential Medicinal Chemistry, $3^{\text {rd }}$ Edition, Hope Publications, Ibadan, Nigeria, pp. 361-63.

Olayiwola, G., Iwalewa, E.O., Omobuwajo, O.R., Adebajo, A.C., Adeniyi, A.A. and Verspohl, J.E. (2004). The antidiabetic potential of Jatropha tanjorensis leaves. Nigerian Journal of Natural Products \& Medicine, 8: $55-58$

Prieto, P., Pineda, M. and Aguilar, M. (1999). Spectrophotometric quantification of antioxidant capacity through the formation of a phosphomolybdenum complex: specific application to the determination of vitamin E. Analytical Biochemistry, 269: 337-41.

Rang, H.P., Dale, M.M., Ritter, J.M. and Flower, R. J. (2007). Rang and Dale's Pharmacology, $6^{\text {th }}$ edition, Churchill Livingstone, London, pp. 405-08.

Roglic, G., Wild, S., Green, A., Richard, S. and Hillary, K. (2004). Prevalence of diabetes. Diabetes Care, 27: 1047-53.

Sathishsekar, D. and Subramanian, S. (2005). Antioxidant properties of Momordica charantia (bitter gourd) seeds on streptozotocin induced diabetic rats. A sia Pacific Journal of Clinical Nutrition, 14: 153-58.

Sofowora, A. (2008). Medicinal Plants and
Traditional Medicine in Africa. $3^{\text {rd }}$ edition, Spectrum Books Ltd., Ibadan, pp. 4, 117-33.

Somsuvra, B., Ghatak S., Panchal, S. (2012). Antidiabetic activity of oryzanol and its relationship with the antioxidant property. International Journal of Diabetes in Developing Countries, 32: 185-92.

Szkudelski, T. (2001). The mechanism of alloxan and streptozotocin action in $\beta$ cells of the rat pancreas. Physiological Research, 50 (6): $: 537-46$

Tilak, J.C., Adhikari, S. and Devasagayam, T.P. (2004). Antioxidant properties of Plum, bago zeylanica, an Indian medicinal plant and its active ingredient, plumbagin. Redox Report, 9: 219-27.

Trease, G.E. and Evans, W.C. (2002). Pharmacognosy, $15^{\text {th }}$ edition, Edinburgh, London, New York, pp. 234, 245, 362.

Trease, G.E. and Evans, W.C. (2009). Pharmacognosy, $16^{\text {th }}$ edition, Edinburgh, London, New York, pp. 533-34.

Udem, S.C., Ezeonuegbu, U.C. and Obidike, R.I. (2011). Experimental studies on the hypolipidemic and haematological properties of aqueous leaf extract of Cleistopholis patens Benth. \& Diels. (Annonacae) in hypercholesterolemic rats. Annals of Medical Health Science and Research, 1:115-22. 